\title{
ON THE COEXISTENCE OF MAN AND EXTINCT PLEISTOCENE MEGAFAUNA AT GRUTA DEL INDIO (ARGENTINA)
}

\author{
Alejandro García \\ CONICET - Departamento de Historia, Facultad de Filosofía, Humanidades y Artes, Universidad Nacional de San Juan, \\ Ignacio de la Roza 230 (Oeste)_5400 San Juan, Argentina. Email: alegarcia@unsj.edu.ar or agarcia@logos.uncu.edu.ar.
}

\begin{abstract}
New excavations and new ${ }^{14} \mathrm{C}$ dates at the Gruta del Indio shelter in the central Argentinean Andes show that the dung layer of the site is much thicker towards the front of the site than near the rock wall. This yields a longer chronology for the dung deposit; thus, the upper boundary would date to about $9000{ }^{14} \mathrm{C} \mathrm{yr} \mathrm{BP}$. The new measurements lengthen the possible time of the coexistence of man and extinct Pleistocene megafauna in the area, since $\sim 1400$ cal yr is much longer than previously thought (Long et al. 1998). Nevertheless, coexistence does not imply interaction, which still is not evident.
\end{abstract}

\section{INTRODUCTION}

Gruta del Indio $\left(34^{\circ} 45^{\prime} \mathrm{S}, 68^{\circ} 22^{\prime} \mathrm{W}\right)$ is a significant point of reference for the discussion of the features of the early human peopling of the central Argentinean Andes and the human relation to the extinction of Pleistocene megafauna (Long and Martin 1973; Lagiglia 1974; García 1999) and to the environmental changes (D'Antoni 1983; Dacar et al. 2001).

Despite the finding of lithic artifacts in the lower stratigraphic levels and of hearths dated to the final Pleistocene (Lagiglia 1956, 1968, 1979), a recent analysis of ${ }^{14} \mathrm{C}$ dates on charcoal and dung samples (Long et al. 1998) from the right area of the shelter (Figure 1) suggests that the coexistence of man and extinct sloths is not certain and, at most, it would have been very short. In Long et al. (1998), a set of 10 dates from dung samples put these materials between $9650 \pm 800$ and 24,730 \pm $860{ }^{14} \mathrm{C}$ yr BP. The calibration $(2 \sigma)$ done by Long et al. (1998:696) for 5 dates with $1 \sigma$ counting errors less than $200 \mathrm{yr}$ indicates maximal ages ranging from about 12,000 to $14,680 \mathrm{cal} \mathrm{yr}$ BP. Another set of 10 dates was obtained from charcoal samples with $1 \sigma$ counting errors less than 200 yr. Results span from $8045 \pm 55$ to $10,530 \pm 140{ }^{14} \mathrm{C}$ yr BP, with calibrated ages $(2 \sigma)$ between 8600 and 12,980 $\mathrm{yr}$ BP. The maximal possible overlap, based mainly on dates A-9493 (dung) and A1638 (charcoal), is of 880 or $930 \mathrm{cal}$ yr, depending on which calibration curve is used, from Burr et al. $1998(12,880-12,000=880)$ or from Hughen et al. $1998(12,980-12,050=930)$.

Otherwise, the probability range $(2 \sigma)$ of a date from dermal ossicles ( $\mathrm{GrN} 5772)$ overlaps or precedes those of 9 dates on charcoal (Long et al. 1998:Figures 4a and 4b). However, because of its origin, Long et al. (1998:698) consider the date on dermal ossicles to be anomalous.

On the basis of this information, the coexistence of man and extinct megafauna would not be clear. Recent excavations, carried out between 1997 and 2000, at the right area of the shelter and near the rain-drop line corresponding to the boundary of R8 and R9 squares (Figure 2), allow for a much broader chronological superposition. This proposal is based on a new series of dates from dung and charcoal samples as well as on stratigraphic observations.

\section{METHODOLOGY}

Previous work at the site pointed out the presence of a layer containing extinct megafauna dung, ranging from about $0.15-0.30 \mathrm{~m}$ thick, although in some areas it could reach $0.40 \mathrm{~m}$ (Semper and Lagiglia 1968:133; Lagiglia 1974). Since these excavations were mainly in an area adjacent to the wall of the shelter (Figure 2), some seemingly anomalous dates (Lagiglia 1974), and the difficulty to determine the chronology of the layer are explained by its lesser width there. 


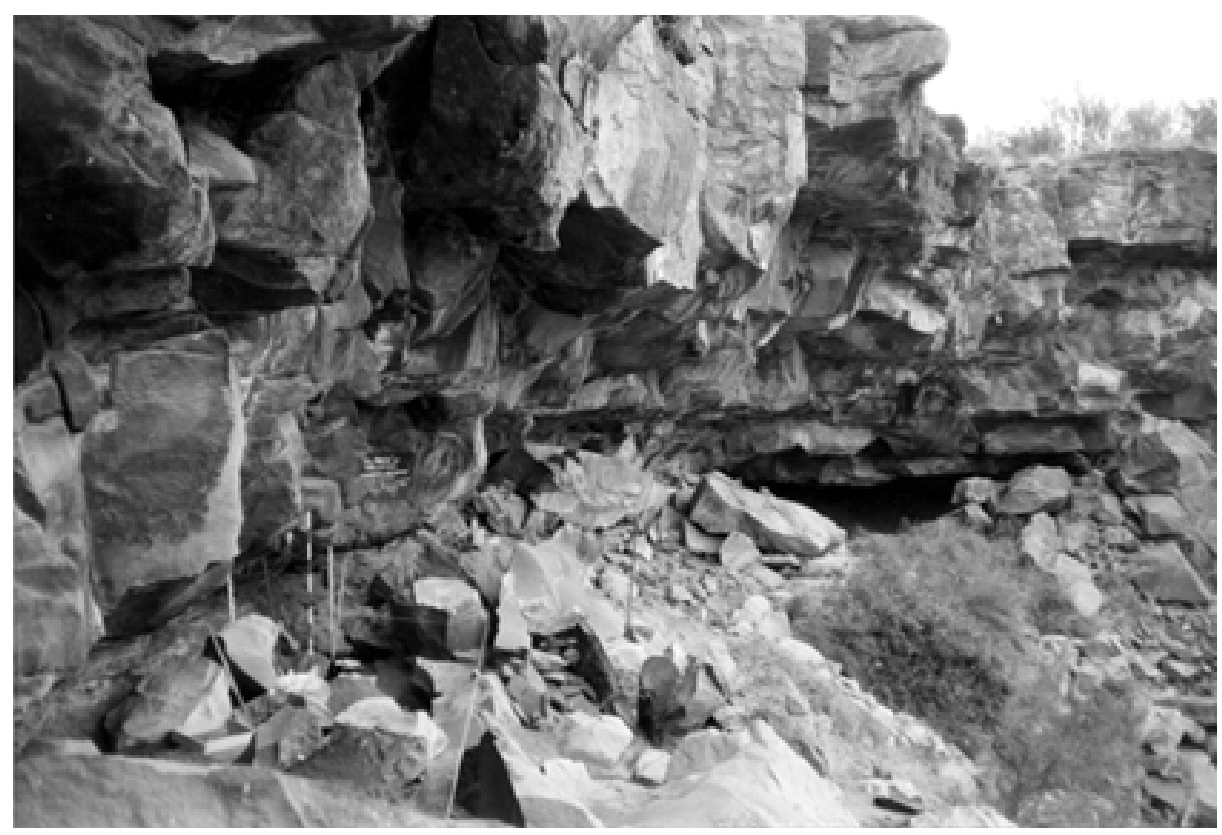

Figure 1 General view of the new excavation at the right area of Gruta del Indio

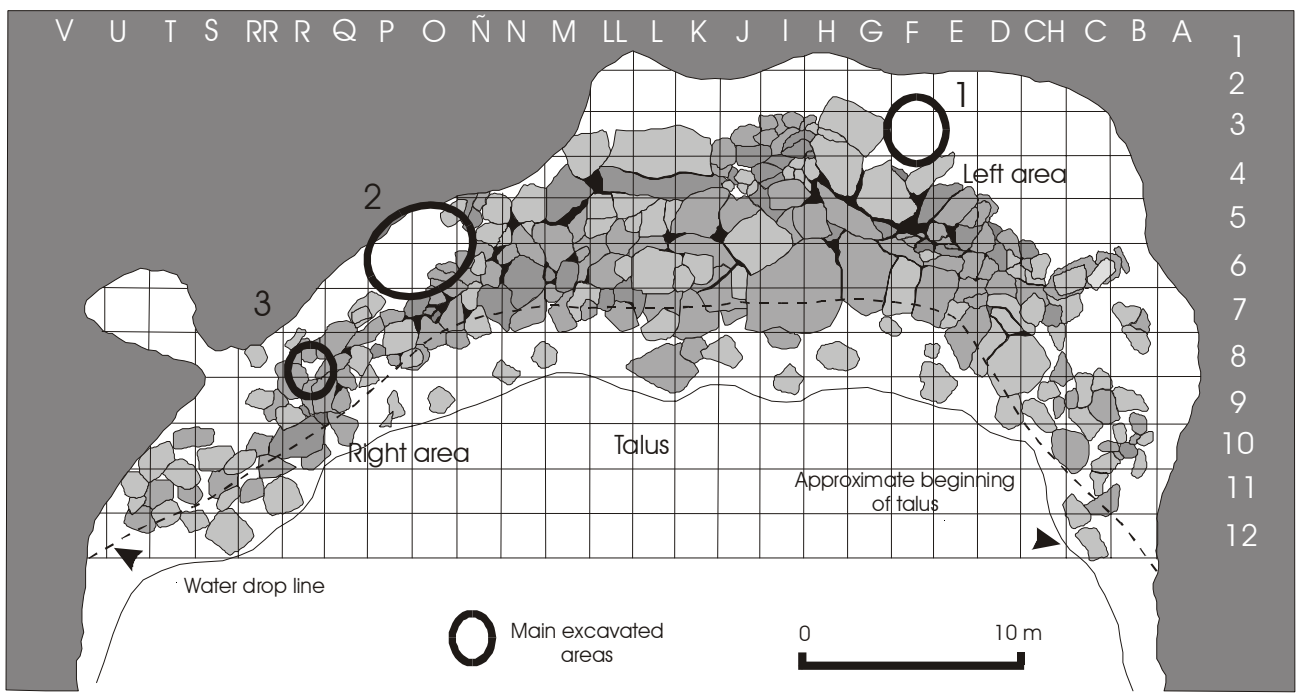

Figure 2 Plan of the site and main areas excavated, re-drawn from Lagiglia 1977: 1=Lagiglia/Semper; 2=Long/Lagiglia; $3=$ García/Lagiglia

In order to minimize disturbance of the site, the new excavation was carried out at a restricted area of some $2 \mathrm{~m}^{2}$ cleared by partially removing two great rocks with a tackle. The results revealed that the layer including the megafauna dung is thicker towards the front of the shelter, at least in the area of squares R8 and R9 (García and Lagiglia 1999). The thickness of the layer reaches $0.9 \mathrm{~m}$, allowing a better chronological control of the deposition periods. This wider stratigraphic distribution of the dung made it possible to obtain new dates that offer a very different view of the chronology of the 
layer. The analyses were run by the Tritium and Radiocarbon Laboratory (Latyr) at the Universidad Nacional de La Plata and Beta Analytic, Inc. According to the results, a thin portion of that layer $(0.10-0.30 \mathrm{~m})$ would have been deposited during the Pleistocene-Holocene transition (Table 2, date $\# 9$ ), while the lower portion (about $0.60 \mathrm{~m}$ ) would have laid between at least $\sim 36,000$ and $\sim 24,000$ yr BP (Table 2, \#10-17).

Taking into account the small size of the recently analyzed dung balls $(\sim 80 \mathrm{~mm})$, the probable presence of Machrauquenia sp. and Hippidion sp. (besides Megatherium sp. and Mylodon sp., see Semper and Lagiglia 1962-1968) in the record (Miotti, personal communication), and the morphological and dimensional similarity to that of actual equines, it is possible that the dung balls do not correspond to ground sloths.

For a better comparison of the results, all dates were calibrated using the Calib revision 4.3 program (Stuiver et al. 1998) and no subtractions to the conventional ages (in order to compensate eventual interhemispheric differences) were made (Figini 1999). To incorporate the date A-1351 to the comparison set, all dates with $1 \sigma$ counting errors $\leq 210 \mathrm{yr}$ were included.

\section{RESULTS AND DISCUSSION}

A date from a dung sample corresponding to the more recent depositions (close to the upper boundary of the layer) gave an approximate age for the end of the megaherbivores occupation at the site. The analyzed material (a single, 64-g dung ball) was taken at a distance of about $0.10-0.20 \mathrm{~m}$ from that boundary (Figure 3). The result was $8990 \pm 90{ }^{14} \mathrm{C} \mathrm{yr} \mathrm{BP} \mathrm{(LP} \mathrm{925).} \mathrm{From} \mathrm{the} \mathrm{same} \mathrm{level} \mathrm{of} \mathrm{LP}$ 925 , we recovered some 60 little fragments of bones presumably belonging to megafauna and a small $(13 \mathrm{~mm})$ flake of rhyolite, probably dispersed vertically by postdepositional disturbance agents (García and Lagiglia 1999b).

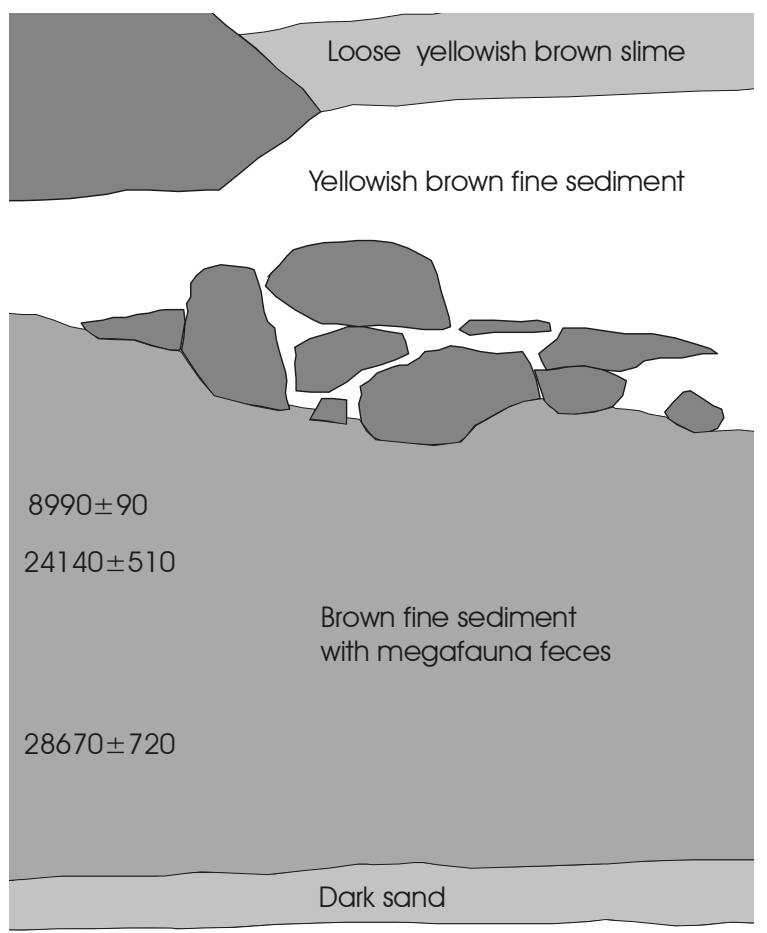

Non-excavated area $20 \mathrm{~cm}$ Focks Figure 3 Pit wall at the R8/R9 boundary 
Moreover, new dates on charcoal samples from previous and present work at squares Ñ, O5, Q7 and RR9 (Lagiglia, personal communication) have been recently obtained. Results range between 7430 \pm 90 and $9700 \pm 110{ }^{14} \mathrm{C} \mathrm{BP}$, with calibrated ages $(2 \sigma)$ between 8030-8390 and 10,690-11,260 BP.

Tables 1 and 2 show the calibrated dates $(2 \sigma)$ only with $1 \sigma$ counting errors less than $200 \mathrm{yr}$ from Long et al. (1998) and the new dates mentioned above. Even if the date on dermal ossicles rejected by Long et al. (1998) is removed, a difference of about $1420 \mathrm{cal}$ yr $(11,780-10,360=1420 \mathrm{cal}$ yr) is recorded between the more conservative possibility of the date - corresponding to the older charcoal sample (A-1638, Table 1, \#2) - and the oldest possible age of the more recent one, corresponding to the younger dung sample (LP-925, Table 2, \#9). Considering $1 \sigma$, the lesser possible difference between the calibrated ages for A-1638 $(12,180-12,890)$ and LP-925 $(9920-10,220)$ is about 1960 cal yr. Finally, the maximal possible difference between the cal ages for both samples $(2 \sigma)$ is 3160 cal yr (12,950-9790 cal yr).

Taking into account the presence of more recent dung (because of its stratigraphic position, see Figure 3), the difference between the ages for the oldest charcoal and the youngest dung could be even greater.

Table 1 Dates with standard deviations $\leq 210 \mathrm{yr}$ from Long et al. (1998:696)

\begin{tabular}{|c|c|c|c|c|c|c|}
\hline $\mathrm{Nr}$ & Material $^{\mathrm{a}}$ & Lab. nr & Coll. $^{b}$ & Origin & Date & Cal $2 \sigma$ Stuiver et al. 1998 \\
\hline 1 & $\mathrm{Ch}$ & GrN 5394 & HAL & $\mathrm{RR} 9,0.7 \mathrm{~m}$ & $8045 \pm 55$ & $8720(9005) 9230$ \\
\hline 2 & $\mathrm{Ch}$ & A-1638 & $\mathrm{AL}$ & $\mathrm{F} 3,2.2 \mathrm{~m}$ & $10530 \pm 140$ & $\begin{array}{l}11780(12429,12455 \\
12361) 12950\end{array}$ \\
\hline 3 & $\mathrm{Ch}$ & A-9486 & $\mathrm{AL}$ & P6-O5, $0.8 \mathrm{~m}$ & $10135 \pm 95$ & $\begin{array}{l}11260(11696,11723, \\
11726) 12340\end{array}$ \\
\hline 4 & $\mathrm{Ch}$ & A-9489 & $\mathrm{AL}$ & O5 & $9905 \pm 140$ & $\begin{array}{l}10890(11240,11246, \\
11255) 11950\end{array}$ \\
\hline 5 & $\mathrm{Ch}$ & A-9491 & $\mathrm{AL}$ & O5 & $9770 \pm 85$ & 10810 (11186) 11330 \\
\hline 6 & $\mathrm{Ch}$ & A-9492 & $\mathrm{AL}$ & Fogón 3 & $9825 \pm 95 / 90$ & $11110(11202) 11550$ \\
\hline 7 & $\mathrm{Ch}$ & A-9495 & $\mathrm{AL}$ & O5 & $9890 \pm 75$ & $11170(11232) 11550$ \\
\hline 8 & $\mathrm{Ch}$ & A-9496 & $\mathrm{AL}$ & O5 & $9990 \pm 75$ & $\begin{array}{l}11200(11303,11315, \\
11339,11396,11519, \\
11539) 11940\end{array}$ \\
\hline 9 & $\mathrm{Ch}$ & A-9497 & $\mathrm{AL}$ & O5 & $10195 \pm 80$ & $\begin{array}{l}11360(11767,11806, \\
11927) 12360\end{array}$ \\
\hline 10 & $\mathrm{Ch}$ & A-9498 & $\mathrm{AL}$ & O5 & $10170 \pm 70$ & $\begin{array}{l}11360(11755,11818, \\
11909) 12340\end{array}$ \\
\hline 11 & $\mathrm{D}$ & GrN 5558 & HAL & $\mathrm{RR} 8,1.1 \mathrm{~m}$ & $10950 \pm 60$ & $12650(12980) 13160$ \\
\hline 12 & $\mathrm{D}$ & A-1351 & HAL & Q7-7, 0.7-0.8 m & $10610 \pm 210$ & $\begin{array}{l}11760(12656,12728, \\
12804) 13120\end{array}$ \\
\hline 13 & $\mathrm{D}$ & A-1371 & HAL & Q7-8, 0.8-0.9 m & $11820 \pm 180$ & $13420(13826) 15250$ \\
\hline 14 & $\mathrm{D}$ & A-9571 & $\mathrm{AL}$ & $\mathrm{P} 6,>0.6 \mathrm{~m}$ & $12375 \pm 115$ & $14100(14325) 15510$ \\
\hline 15 & $\mathrm{D}$ & A-9570 & $\mathrm{AL}$ & $\mathrm{P} 6,>0.6 \mathrm{~m}$ & $11040 \pm 130$ & $12660(13013) 13370$ \\
\hline 16 & $\mathrm{D}$ & A-9493 & $\mathrm{AL}$ & $\mathrm{P} 6,>0.6 \mathrm{~m}$ & $10900 \pm 185$ & 12390 (12944) 13190 \\
\hline 17 & $\mathrm{~B}$ & GrN 5772 & HAL & RR-9-7, $0.7 \mathrm{~m}$ & $9560 \pm 90$ & $\begin{array}{l}10580(10767,10832, \\
10837,10957,11006, \\
11017,11059) 11180\end{array}$ \\
\hline
\end{tabular}

${ }^{\mathrm{a}} \mathrm{Ch}=$ charcoal; $\mathrm{D}=$ dung; $\mathrm{B}=$ bone

${ }^{\mathrm{b}}$ Coll. $=$ Collector: $\mathrm{AL}=$ Austin Long; $\mathrm{HAL}=$ Humberto Lagiglia 
Table 2 Dates recently obtained for lower layer at Gruta del Indio

\begin{tabular}{|c|c|c|c|c|c|c|}
\hline $\mathrm{Nr}$ & Material $^{\mathrm{a}}$ & Lab. nr & Coll. ${ }^{b}$ & Origin & Date & 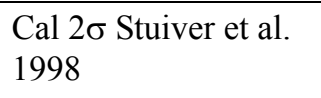 \\
\hline 1 & $\mathrm{Ch}$ & LP-860 & HAL & $\mathrm{O} 5,1 \mathrm{~m}$ & $9590 \pm 120$ & $\begin{array}{l}10560(10794,10795, \\
10809,10823,10860, \\
10940,11068) 11230\end{array}$ \\
\hline 2 & $\mathrm{Ch}$ & LP-941 & HAL & RR9, 0.7 m & $9580 \pm 100$ & $\begin{array}{l}10580(10790,10802, \\
10805,10827,10851 \\
10941,11065) 11200\end{array}$ \\
\hline 3 & $\mathrm{Ch}$ & LP-991 & HAL & $\begin{array}{l}\tilde{\mathrm{N}} 4-1, \\
0.38-0.48 \mathrm{~m}\end{array}$ & $9510 \pm 90$ & $10510(10740) 11160$ \\
\hline 4 & $\mathrm{Ch}$ & LP-986 & HAL & $\begin{array}{l}\text { O5-2, } \\
0.72-0.9 \mathrm{~m}\end{array}$ & $9160 \pm 90$ & $\begin{array}{l}10180(10242,10352, \\
10355) 10580\end{array}$ \\
\hline 5 & $\mathrm{Ch}$ & LP-876 & HAL & $\begin{array}{l}\mathrm{O} 5 \\
0.8-0.9 \mathrm{~m}\end{array}$ & $9700 \pm 110$ & $10690(11165) 11260$ \\
\hline 6 & $\mathrm{Ch}$ & LP-854 & HAL & $\begin{array}{l}\text { Q7-5, } \\
0.5-0.6 \mathrm{~m}\end{array}$ & $8920 \pm 110$ & $\begin{array}{l}9600(9977,9986, \\
10151) 10240\end{array}$ \\
\hline 7 & $\mathrm{Ch}$ & LP-873 & HAL & $\begin{array}{l}\text { Q7, } \\
0.35-0.4 \mathrm{~m}\end{array}$ & $7430 \pm 90$ & $\begin{array}{l}8030(8195,8296, \\
8278) 8390\end{array}$ \\
\hline 8 & $\mathrm{Ch}$ & LP-845 & HAL & $\mathrm{O} 5,0.8 \mathrm{~m}$ & $7860 \pm 90$ & $\begin{array}{l}8420(8606,8620 \\
8628) 9010\end{array}$ \\
\hline 9 & $\mathrm{D}$ & LP-925 & $\mathrm{AG}$ & $\mathrm{R} 8 / 9$ & $8990 \pm 90$ & 9790 (10190) 10360 \\
\hline 10 & $\mathrm{D}$ & LP-929 & $\mathrm{AG}$ & $\mathrm{R} 8 / 9$ & $30200 \pm 800$ & - \\
\hline 11 & $\mathrm{D}$ & LP-918 & $\mathrm{AG}$ & $\mathrm{R} 8 / 9$ & $30800 \pm 700$ & - \\
\hline 12 & $\mathrm{D}$ & LP-1072 & $\mathrm{AG}$ & $\mathrm{R} 8 / 9$ & $28670 \pm 720$ & - \\
\hline 13 & $\mathrm{D}$ & LP-1075 & $\mathrm{AG}$ & $\mathrm{R} 8 / 9$ & $24140 \pm 510$ & - \\
\hline 14 & $\mathrm{D}$ & Beta 152587 & $\mathrm{AG}$ & R9 & $>37610$ & - \\
\hline 15 & $\mathrm{D}$ & Beta 152588 & $\mathrm{AG}$ & R9 & $29530 \pm 540$ & - \\
\hline 16 & $\mathrm{D}$ & Beta 152589 & $\mathrm{AG}$ & R9 & $36400 \pm 200$ & - \\
\hline
\end{tabular}

${ }^{\mathrm{a}} \mathrm{Ch}=$ charcoal; $\mathrm{D}=$ dung; $\mathrm{B}=$ =one

${ }^{\mathrm{b}}$ Coll. $=$ collector: $\mathrm{HAL}=$ Humberto Lagiglia; $\mathrm{AG}=$ Alejandro García

Also, date LP-925 is younger than 9 other dates from charcoal samples given by Long et al. (1998: Table 1, \#2-10), and younger than 5 of the new results obtained by Lagiglia (Table 2, \# 1-5).

According to the tables above and assuming that the age of the dung and the charcoal from the site constitutes an adequate instrument to solve the problem, the possible time of man and megafauna coexistence in the area of Gruta del Indio would be much greater than previously thought. This situation would not be rare given the available information for the early human peopling of the region, as indicated by the archaeological record of Agua de la Cueva rockshelter (200 km north) with an initial occupation dated to $10,950 \pm 190{ }^{14} \mathrm{C}$ yr BP (García et al. 1999).

Nevertheless, this is not a proof for the interaction between man and megafauna. On the contrary, the signals are scarce (Semper and Lagiglia 1962-1968; Lagiglia 1979) and eventually suggest a very sporadic presence of man at the site during the Pleistocene-Holocene transition. Otherwise, although attention has been focused on the overlap of dates from dung and charcoal samples, better proof is still needed for the cultural origin of that charcoal. The absence of burnt dung in the area of R8/9 suggests that no natural fires expanding throughout the site would have occurred, so the charcoal recorded could have a cultural origin. Notwithstanding, recent observations point out marked 


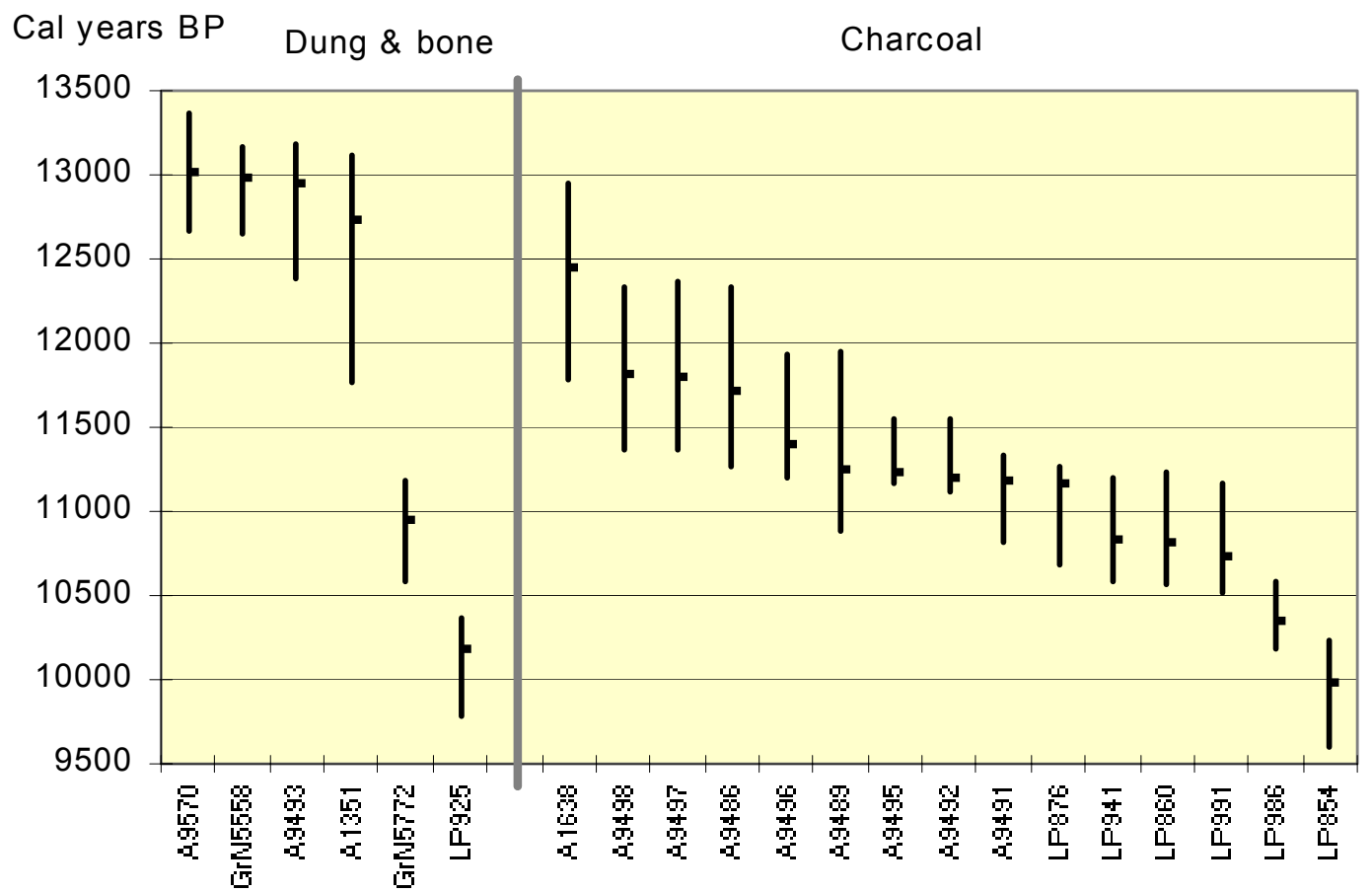

Figure 4 Overlap of probability ranges of calibrated dates $(2 \sigma)$

stratigraphic differences at neighboring areas of the site (García 2001), whereas the sole presence of definite charcoal patches or lines does not imply a cultural origin (García and Zárate 1999).

Due to the scarcity of lithic artifacts (Lagiglia 1979) and their lack of direct association with the charcoal and megafauna items (Borrero 2002), the most fruitful way to prove the interaction of man and Pleistocene megafauna (not considering new excavations in the central area of the site) seems to be the study of the osseous material showing probable cultural marks, discovered at the right area of the shelter (Semper and Lagiglia 1962-1968; García and Lagiglia 1999).

\section{CONCLUSIONS}

The ${ }^{14} \mathrm{C}$ dates from Gruta del Indio indicate that several episodes of charcoal burning occurred during at least the last $1400 \mathrm{cal}$ yr of existence of the Pleistocene megafauna around the site. If the cultural character of that charcoal is accepted (Long et al. 1998) and an effective interaction is assumed (Lagiglia 1974), the time of coexistence between man and Pleistocene megafauna in the area could be so prolonged as to allow interaction and the incidence of the former to the extinction. However, to prove that interaction, firmer, more solid evidence is still required, which could come from the future discovery of cultural artifacts and megafauna items in direct association or from the analysis of use-traces and fractures on the archaeofaunistic material presently available.

\section{ACKNOWLEDGMENTS}

To Humberto Lagiglia, for his suggestions and help in the fieldwork, and to the owners of the Campo Limeño for permitting us the access to the site. I also wish to thank Paul Martin and Austin Long for their helpful comments on the manuscript. Recent research at Gruta del Indio was supported by Fundación Antorchas. 


\section{REFERENCES}

Borrero LA. 2002. Arqueología y biogeografía humana en el sur de Mendoza. In: Gil A, Neme G, editors. Entre montañas y desiertos: arqueología del sur de Mendoza. p 195-202.

Burr GS, Beck JW, Taylor FW, Recy J, Edwards RL, Cabioch G, Corrège T, Donahue DJ, O’Malley JM. 1998. A high-resolution radiocarbon calibration between 11,700 and 12,400 calendar years BP derived from ${ }^{230} \mathrm{Th}$ ages of corals from Espiritu Santo Island, Vanuatu. Radiocarbon 40(3):1093-105.

Dacar M, Borghi C, Martínez Carretero E, Giannoni S, García A. 2001. Paleodiet of Cavidae rodents in the Monte Desert of Argentina in the last 30,000 years. Current Research in the Pleistocene 18:95-7.

D’Antoni H. 1983. Pollen analysis of Gruta del Indio. Quaternary of South America and Antarctica Peninsula. p 83-103.

Figini A. 1999. Análisis de la calibración en años calendarios de las edades C-14. Corrección para el Hemisferio sur. In: Actas del XII Congreso Nacional de Arqueología Argentina II:349-52.

García A. 1999. La extinción de la megafauna pleistocénica en los Andes Centrales Argentino-Chilenos. Revista Española de Antropología Americana 29:930.

García A. 2001. Estado actual de los estudios sobre el poblamiento temprano del centro de Mendoza. Paper presented at XIV Congreso Nacional de Arqueología Argentina.

García A, Lagiglia H. 1999a. A 30,000-year-old Megafauna dung layer from Gruta del Indio (Mendoza, Argentina). Current Research in the Pleistocene 16:11618.

García A. 1999b. Avances en el estudio del registro pleistocénico tardío de la Gruta del Indio (Mendoza). In: Cuadernos del Instituto Nacional de Antropología y Pensamiento Latinoamericano 18:167-74.
García A, Zárate M. 1999. Perdurabilidad y cambios de fogones experimentales en la precordillera mendocina. Arqueología 9:105-21.

García A, Zárate M, Páez M. 1999. The Pleistocene-Holocene transition and human occupation in the Central Andes of Argentina: Agua de la Cueva locality. Quaternary International 53/54:43-52.

Hughen KA, Overpeck JT, Lehman SJ, Kashgarian M, Southon J, Peterson LC, Alley R, Sigman DM. 1998. Deglacial changes in ocean circulation from an extended radiocarbon calibration. Nature 391:65-8.

Lagiglia H. 1956. Estudios Arqueológicos en el Rincón del Atuel (Departamento San Rafael, Mendoza). Anales de Arqueología y Etnología XII:227-87.

Lagiglia H. 1974. Atuel IV frente a la prehistoria americana. Paper presented at III Congreso Nacional de Arqueología Argentina. Salta.

Lagiglia H. 1977. Arqueología y ambiente natural de los valles del Atuel y Diamante. PhD dissertation. Facultad de Ciencas Naturales y Museo, UNLP.

Lagiglia H. 1979. Dinámica cultural en el centro oeste y sus relaciones con áreas aledañas argentinas y chilenas. In: Actas del VII Congreso de Arqueología de Chile II:531-60.

Long A, Martin P. 1973. Death of American Ground Sloths. Science 186:638-40.

Long A, Martin P, Lagiglia H. 1998. Ground Sloths and humans at Gruta del Indio-Argentina. Radiocarbon 40(2):693-700.

Semper J, Lagiglia H. 1962-1968. Excavaciones arqueológicas en el Rincón del Atuel (Gruta del Indio). Revista Cientifica de Investigaciones I(4):89-158.

Stuiver M, Reimer PJ, Bard E, Beck JW, Burr GS, Hughen KA, Kromer B, McCormac FG, van der Plicht J, Spurk M. 1998. INTCAL 98 radiocarbon age calibration, 24,000-0 cal BP. Radiocarbon 40(3):104183. 